\title{
Razmišljanja i razina znanja o palijativnoj skrbi kod studenata studija sestrinstva u Dubrovniku
}

1 Vedrana Iveta

2 Mara Županić

3 Dubravka Bartolek Hamp

4 Anita Miljas

1 Dom zdravlja Dubrovnik

2 Zdravstveno veleučilište Zagreb

3 Klinički bolnički centar Zagreb

4 Opća bolnica Dubrovnik

\section{Sažetak}

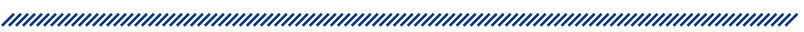

Uvod: Palijativna skrb (PS) još je uvijek velika nepoznanica, kao i samom značenje te riječi. Danas, nakon što se pojam PS u medicini već desetak godina aktivno upotrebljava u našoj zemlji, možemo reći da je neznanja još uvijek dosta kako među zdravstvenim djelatnicima tako i u ostaloj populaciji. Sam naziv nosi „stigmu” uzrokovanu nedovoljnim znanjem i edukacijom. Upravo edukacija predstavlja ključni element u aktivnijoj primjeni resursa PS-a u svim fazama bolesti, kod bolesnika kojima je takva skrb potrebna. PS je i sveobuhvatna skrb primjerena teško oboljelom pacijentu čije se potrebe prepoznaju i uklanjaju multidisciplinarnim i holističkim pristupom.

Cilj ovog istraživanja bio je utvrditi znanja i stavove studenata sestrinstva o palijativnoj skrbi te ustanoviti u kolikoj mjeri njihova dob, edukacija te iskustvo ili radno mjesto imaju utjecaja na njihovo razmišljanje o palijativnoj skrbi.

Metode istraživanja: Istraživanje je provedeno dobrovoljnom i anonimnom anketom studenata na preddiplomskom i diplomskom studiju sestrinstva pri Sveučilištu u Dubrovniku. U anketu su bili uključeni studenti u radnom odnosu i nezaposleni studenti te studenti zdravstvene i nezdravstvene struke. Mjerni instrument primijenjen u ovom presječnom istraživanju bio je standardizirani upitnik PCQN (Palliative Care Quiz for Nurses). Upitnik sadrži 20 pitanja koja se odnose na filozofiju palijativne skrbi, kontrolu boli i pridruženih simptoma bolesti te psihičku, duhovnu i socijalnu problematiku PS-a. Ponuđeni odgovori na pitanja bili su: točno, netočno i ne znam. Točan odgovor bio je bodovan jednim bodom, dok su odgovori ne znam i netočno analizirani kao nula bodova. U statističkoj analizi primijenjena je analiza varijance (ANOVA) uz Kruskal-Wallisov i Mann-Whitneyjev U-test.

Rezultati: Većina ispitanika smatrala je da je dobro što se danas u izvedbeni plan studija uveo predmet Palijativna skrb (55,4\%). Nijedan student nije točno odgovorio na više od 12 pitanja, što u usporedbi s istovrsnim studijama drugih autora ukazuje na činjenicu da među našim ispitanicima postoji temeljno znanje.

Ključne riječi: palijativna skrb, medicinska sestra, PCQN upitnik, studij sestrinstvo

Datum primitka: 21.9.2021.

Datum prihvaćanja: 15.11.2021.

https://doi.org/10.24141/1/8/1/7

Osoba za kontakt:

Vedrana Iveta

GSM:+385 915162262

E-pošta:vedrana.iveta@gmail.com 


\section{UVOD}

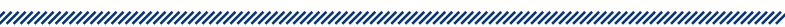

Pravo na palijativnu skrb Svjetska zdravstvena organizacija (SZO) 1990. proglasila je i definirala jednim od osnovnih ljudskih prava na zdravstvenu zaštitu.

Cilj je palijativne skrbi uz smanjenje neugodnih simptoma bolesti osigurati adekvatnu analgeziju do podnošljivosti boli te zadovoljiti osnovne rehidracijske i temeljne nutricijske potrebe kako bi bolesnik koji je u posljednjim stadijima neizlječivih bolesti ili teške kronične bolesti što kvalitetnije proživio preostali dio života. Palijativni multidisciplinarni tim čine stručnjaci različitih struka koji pristupaju samom bolesniku, ali i usko surađuju s članovima njegove obitelji. U timu surađuju liječnici, medicinske sestre, socijalni radnici, psiholozi, farmaceuti, duhovnici i volonteri. Palijativnom medicinom nastoji se pomoći bolesniku na tjelesnom, duševnom i duhovnom planu. Palijativna skrb odvija se dijelom u bolnicama, u posebnim ustanovama namijenjenima za palijativnu skrb, tzv. hospicijima, no većinom se još uvijek provodi u sklopu domova za starije i nemoćne osobe te uz samo liječenje u kući bolesnika. ${ }^{1}$

Palijativni pristup zamišljen je kao način za integraciju metoda palijativne skrbi i postupaka u općem sustavu skrbi (kao što je interna medicina, skrb o starijim osobama itd.).

Opća palijativna skrb namijenjena je zdravstvenim radnicima koji su često involvirani u pružanje palijativne skrbi pacijentima ili postupaju kao spasilačko osoblje za palijativnu skrb u svojem području djelovanja, ali za koje palijativna skrb nije glavni fokus njihove kliničke prakse (npr. liječnici primarne zdravstvene zaštite, onkolozi, stručnjaci gerijatrije, medicinske sestre i medicinske sestre specijalizirane za kliničku medicinu).

Specijalistička palijativna skrb odnosi se na zdravstvene djelatnike koji rade isključivo u području palijativne skrbi. Njezina je glavna aktivnost usmjerena na rješavanje kompleksnih problema koji zahtijevaju specijalističke vještine i kompetencije. Neke su zemlje preuzele ove razine i prilagodile ih svojoj situaciji na terenu. U nekim slučajevima uvedene su daljnje podjele ovih razina kako bi se prikazale uloge i odgovornosti u pružanju usluga na nacionalnoj razini. Dobar je primjer takvog sustava Švicarska. ${ }^{1,2}$

Palijativna medicina ne može izliječiti osobu, ali može o njoj skrbiti, ublažiti joj bol i patnju, čuvajući dostojanstvo osobe kao jedinstvenoga ljudskog bića. ${ }^{2}$

\section{ULOGA MEDICINSKE SESTRE U PALIJATIVNOJ SKRBI}

Sestrinstvo je spoj aktivnosti zasnovan na praksi. Jezgra je humana priroda, profesionalna njega i izgradnja terapeutskih relacija s praksom uključenja medicinskih sestara i tehničara u kompleksan proces donošenja odluka. Njega pacijenta primarna je odgovornost medicinskih sestara i tehničara u palijativnoj skrbi. Kako se pacijentova uloga mijenja od bolesnika do umirujućeg, sestra je primarna osoba koja pacijentu i njegovoj obitelji dan za danom pruža utjehu, podršku i pomoć. Primarna uloga sestre u palijativnoj njezi nikad se nije mijenjala, ostala je jedinstvena i tijekom 20. stoljeća, a i danas. Postoji šest međusobno isprepletenih i diskretnih dimenzija koje opisuju ulogu medicinske sestre u palijativnoj skrbi, uključujući procjenjivanje, povezivanje, osnaživanje, rad za bolesnika, pronalaženje svrhe i očuvanje integriteta., ${ }^{2}$ Procjenjivanje poštuje svojevrsnu vrijednost drugih. To uključuje neosuđujući stav uz globalno procjenjivanje. Posebno procjenjivanje osobno je i ne može se ostvariti dok medicinska sestra ne izgradi odnos s pacijentom. Povezivanje se odnosi na povezanost medicinske sestre, pacijenta i obitelji te uključuje dvije komponente povezivanja:

održavanje veze: biti dostupan, provoditi vrijeme, dijeliti bolesnikove osobne misli i bojazni, davati ohrabrenja za svladavanje svakodnevnih poteškoća u bolesti

prekidanje veze: često se događa kad pacijent umre, ali sestra može nastaviti pružati podršku obitelji pacijenta u žalovanju.

Osnaživanje je važan čimbenik u sestrinstvu, a znači osposobljavanje i pacijenta i obitelji da se brinu sami za sebe. To je pružanje snage i okrepljenje. Važna je komponenta osnaživanja ohrabrivanje pacijenta i njegove obitelji da učine ono što žele. Rad za bolesnika uključuje povezivanje s različitim vanjskim izvorima radi dobrobiti pacijenta i njegove obitelji. Tako se u ovom radu može istaknuti model vodstva i/ili timski rad. Uzimanje vodstva obuhvaća kontrolu nad boli i simptomima te pomaganje u osnovnim životnim potrebama bolesnika. Timski rad uključuje pregovaranje u svrhu postizanja najboljih dogovora povezanih s palijativnom skrbi pacijenta, a ovisnih o njegovu aktualnom stanju. U ovom slučaju skupina radi kao pacijentov zastupnik.

Sestra pomaže pacijentu u pronalaženju smisla i razumijevanju svoje situacije. To znači osnaživanje i davanje snage te usmjeravanje na žalovanje i stvaranje saznanja o skoroj smrti, što zahtijeva pomaganje pacijentu da pronađe smisao žaljenja sa svojom bolešću i 
prognozom. To uključuje pomaganje pacijentima da žive punim životom dok ne umru. Stvaranje saznanja o smrti zahtijeva od sestre da ne izbjegava razgovor o tome, već da razgovora o preostalom vremenu. ${ }^{3}$ Čuvanje integriteta znači da sestra u palijativnoj njezi mora posjedovati osjećaj poštovanja i vrijednosti prema sebi. Ona smanjuje stres primjenjujući posebne strategije distanciranja koristeći se humorom ili sakrivajući osobna osjećanja kako bi se zaštitila. Sestra održava svoje samopoštovanje preispitivanjem osjećaja, procjenjivanjem same sebe i preispitivanjem svojeg ponašanja. Ovo pomaže u preispitivanju osnovnih ljudskih vrijednosti i daje snagu za nastavak. Sestra mora biti sigurna da je ono što radi ispravno iz pravih razloga. Samo uz očuvanje vlastitog integriteta sestra je sposobna pronalaziti smisao u svojem poslu i pomagati pacijentima i obitelji u njihovim situacijama. ${ }^{3,5}$

Palijativni pacijent jest osoba čija bolest nadilazi sve mogućnosti liječenja prema suvremenim medicinskim saznanjima. No uz prihvaćanje i razumijevanje postojeće dijagnoze, palijativni bolesnik ima iza sebe cijeli svoj život, ljude koje voli, planove i želje koje još želi ostvariti, kao i osmisliti sve drugo što čini život svake osobe u granicama postojećih, novonastali mogućnosti. ${ }^{5}$

\section{BRIGA O ČOVJEKU U PALIJATIVNOJ SKRBI}

Važno je istaknuti da rad u palijativnoj skrbi nije zvanje, nego osobni izbor. Osoba koja se želi baviti pružanjem palijativne skrbi trebala bi posjedovati najmanje osobine kao što su fleksibilnost, autonomnost odlučivanja, osjećajnost, otvorenost i duhovnost. Fleksibilnost je nužna u rješavanju kompleksnih situacija u kojima se nalaze pacijenti, obitelj i osoblje koje često može biti pod stresom zbog žalosti. Autonomija je nužna radi odgovornog i povjerljivog donošenja neovisnih odluka te preuzimanja odgovornosti za poduzete korake. Osjećajnost je potrebna za vrijednosne i religijske sustave unutar široke raznolikosti među ljudima i kulturama te za stjecanje bolje prosudbe tijekom cjelokupnog pružanja palijativne skrbi. Otvorenost prema novim zamislima, informacijama, pristupima te različitim mišljenjima i stavovima omogućuje razvoj kreativnosti i spontanosti u individualnom pristupu svakom bolesniku. Duhovnost pak ima ishod u poštivanju sebe i drugih te u prepoznavanju vrijednosti vjerskih sustava i ozračja. ${ }^{4}$

Svaki član palijativnoga tima provodi intervencije za koje je zadužen, ali neprestano surađuje s ostalim članovima tima kako bi uspješno ublažili ili riješili postojeće probleme. $^{2}$
Hipokrat je već u antičko doba istaknuo da se medicina ne može prakticirati bez smisla za humanost. ${ }^{5}$ Tako se osnovne etičke vrijednosti, kako u palijativnoj medicini tako i u skrbi, ostvaruju kroz četiri temeljna etička načela: dobročinstvo i neškodljivost te autonomnost $\mathrm{i}$ pravednost koja uključuje istinoljubivost i povjerenje. ${ }^{6}$

\section{STRUČNI STUDIJ SESTRINSTVA DUBROVNIK}

Studij sestrinstva u Dubrovniku relativno je „mlad” studij koji djeluje od 2008., kada je prvobitno otvoren preddiplomski studij, da bi 2014. započeo s radom i diplomski studij kliničkog sestrinstva. Od otvaranja, diplomski studij predviđen je za upis novih studenata svake druge godine.

Studij kontinuirano upisuje 20 do 25 studenata. Studenti slušaju predmet Palijativna zdravstvena njega kao obvezan predmet od 2014., a do tada je područje palijativne skrbi dijelom obrađivano kroz predmet Zdravstvena njega gerijatrijskih bolesnika. Ujednačavanjem programa na razini Republike Hrvatske 2014. predmet je izdvojen kao zaseban i obvezan. Nakon odslušanog kolegija student može objasniti filozofiju i načela palijativne zdravstvene njege, navesti organizacijske oblike i razine palijativne skrbi, identificirati osnovna obilježja palijativne njege u bolnici, hospiciju i zajednici, procijeniti potrebe te planirati, provoditi i evaluirati palijativnu zdravstvenu njegu, primijeniti postupke rješavanja i ublažavanja simptoma i patnje bolesnika, organizirati profesionalnu i socijalnu podršku bolesniku i njegovoj obitelji te komentirati etička pitanja u palijativnoj njezi. ${ }^{7}$

Diplomski studij kliničkog sestrinstva također u svojem izvedbenom planu i programu ima predmet Palijativna skrb u kliničkoj praksi, koji je također obvezan predmet. U kolegij su uključena teorijska i praktična primjena znanja usmjerena na zdravstvenu njegu bolesnika u terminalnom stadiju bolesti s posebnim naglaskom na holistički, sustavan i individualiziran pristup, uz naglasak na bitne principe palijativne skrbi primjenjive u praksi. Palijativna je skrb okvir hospicijske skrbi, s naglaskom na kvalitetu života, palijaciju simptoma, komunikaciju, rješavanje i ublažavanje simptoma, uključivanje obitelji i skrb za obitelj u procesu žalovanja. ${ }^{8}$

\section{PALIJATIVNA SKRB U DUBROVAČKO- NERETVANSKOJ ŽUPANIJI}

Osnovni je uvjet za formiranje palijativnog tima edukacija pri Centru za palijativnu medicinu, medicinsku etiku i komunikacijske vještine Medicinskog fakulteta 
Sveučilišta u Zagrebu (CEPAMET). CEPAMET je osnovan odlukom Fakultetskog vijeća 2010. kao znanstveno-nastavna i stručna organizacijska jedinica Fakulteta u kojoj se obavljaju djelatnosti iz područja palijativne medicine, medicinske etike i komunikacijskih vještina te daju stručno-konzilijarna mišljenja i vještačenja iz tog područja rada. ${ }^{9}$

Za potrebe stanovništva koje zahtijeva palijativnu skrb, 28. travnja 2014. uspostavljen je stacionarni kapacitet u sklopu Opće bolnice Dubrovnik. U rujnu 2015. pri Domu zdravlja Dubrovnik uspostavljen je mobilni palijativni tim koji djeluje u početku s osnovnim članovima tima: medicinska sestra i liječnik specijalist interne medicine. Prema potrebama koji se utvrđuju na terenu u tim se uključuju i ostali članovi: psiholog, socijalni radnik, kirurg, anesteziolog, onkolog, duhovnik i sl. Time je mobilni palijativni tim dosegnuo višu razinu. Odnedavno su na otoku Korčuli i području doline Neretve uspostavljeni uvjeti za otvaranje timova i ugovaranje koordinatora mobilnih timova. Sve institucije na području županije koje pružaju bilo koji oblik palijativne skrbi omogućavaju studentima da teorijska znanja prošire i upoznaju kroz praktične vještine.

CILJ RADA bio je utvrditi znanja i stavove studenata sestrinstva sa Sveučilišta u Dubrovniku o palijativnoj skrbi te ustanoviti u kolikoj mjeri njihova dob, edukacija te iskustvo ili radno mjesto imaju utjecaja na njihovo razmišljanje o palijativnoj skrbi (PS).

HIPOTEZA Pretpostavili smo:

H1 Nema znatne razlike u stavovima i znanjima studenata o PS-u u odnosu na njihovo radno mjesto, radno iskustvo i edukaciju te spol i dob.

H2 Općenito znanje studenata studija sestrinstva o PSu površno je i nedovoljno.

H3 Postoji razlika u stavovima i znanjima o PS-u s obzirom na studijsku godinu, odslušani predmet Palijativna skrb te o tome jesu li studenti zdravstvene struke.

\section{ISPITANICI I METODE}

Istraživanje je provedeno na populaciji studenata Sveučilištu u Dubrovniku u sklopu preddiplomskog i diplomskog studija sestrinstva tijekom jednomjesečnog razdoblja, od 1. do 31. svibnja 2019.

Mjerni instrument primijenjen za utvrđivanje hipoteze u ovom presječnom istraživanju bio je standardizirani anketni upitnik PCQN (Palliative Care Quiz for Nurses) koji su 1996. izradili Ross i suradnici u Kanadi. ${ }^{19}$ Upitnik se sastoji od 20 pitanja koja se odnose na filozofiju palijativne skrbi, kontrolu boli, psihičku, socijalnu i duhovnu problematiku te kontrolu simptoma osnovne bolesti. ${ }^{9}$ Ponuđeni odgovori na postavljena pitanja bili su: točno, netočno i ne znam. Točan odgovor bio je bodovan jednim (1) bodom, dok su odgovori ne znam i netočno analizirani kao nula (0) bodova.

Osim pitanja postavljenih standardiziranim upitnikom, obrađena su još tri pitanja povezana s mišljenjem ispitanika o samoj važnosti palijativne skrbi i potrebi za edukacijom osoblja koje radi u palijativnoj skrbi te osam pitanja koja su se odnosila na demografske karakteristike samih studenata, ispitanika.

Svim potencijalnim ispitanicima prije ulaska u istraživanje pojašnjeno je da je anketa u potpunosti dobrovoljna i anonimna. Anketa je formatirana u klasičnom obliku.

Statističke metode. U sklopu istraživanja kvantitativni demografski podaci prikazani su numerički kao srednja vrijednost sa standardnom devijacijom ili proporcija u postotnom iznosu. Usporedna razlika testirana je Studentovim t-testom i hi-kvadrat testom.

Budući da su pojedine promatrane skupine znatno različitih veličina, primijenjeno je neparametrijsko testiranje analize varijance (ANOVA; Analysis of Variance). Analiza odgovora anketnog upitnika PCQN i načina na koji promatrani parametri analize utječu na vrijednost promatranih kategorija provedena je uz Kruskal-Wallisov i Mann-Whitneyjev U test. Mann-Whitneyjevim U-testom analizirana je skupina anketnih podataka povezana s dvije varijable, dok su Kruskal-Wallisovim testom analizirani podaci sadržani u više od dvije varijable. Statistički značajna razlika prihvaćena je uz $p<0,05$.

\section{REZULTATI ISTRAŽIVANJA}

Istraživanje je obuhvatilo ukupno 101 ispitanika, od kojih je prema stupnju edukacije 63 (62\%) studenta bilo s preddiplomskog, 14 (14\%) studenata s diplomskog studija te 24 (24\%) apsolventa.

Od ukupnog broja ispitanika 21 (21\%) student nije bio iz strukovnog, zdravstvenog smjera.

Sobzirom na spol, među ispitanicima je bio znatno veći broj studentica $(91 ; 90 \%)$ i $10 \%$ studenata.

Dob ispitanika uglavnom je bila u korelaciji s postotkom studenata na određenom stupnju edukacije. Prema tome, najviši postotak studenata ispitanika (61 \%) imao je od 18 do 24 godine (34\% je bilo između 25 i 35 godina, a $5,0 \%$ je imalo 35 i više godina) (tablica 1 ) 


\begin{tabular}{c|c|c|c|}
\hline \multicolumn{4}{|c}{ Tablica 1. Demografske karakteristike } \\
ispitanika
\end{tabular}

Prema profesionalnom statusu, medicinske sestre / medicinski tehničari činili su 68,3\% ispitanika, a prvostupnice/prvostupnici sestrinstva 10,9\%. Dvadeset jedan ispitanik (nezdravstvenog smjera) (20,8 \%) nije bio ni u jednoj od ovih dviju kategorija (grafikon 1).

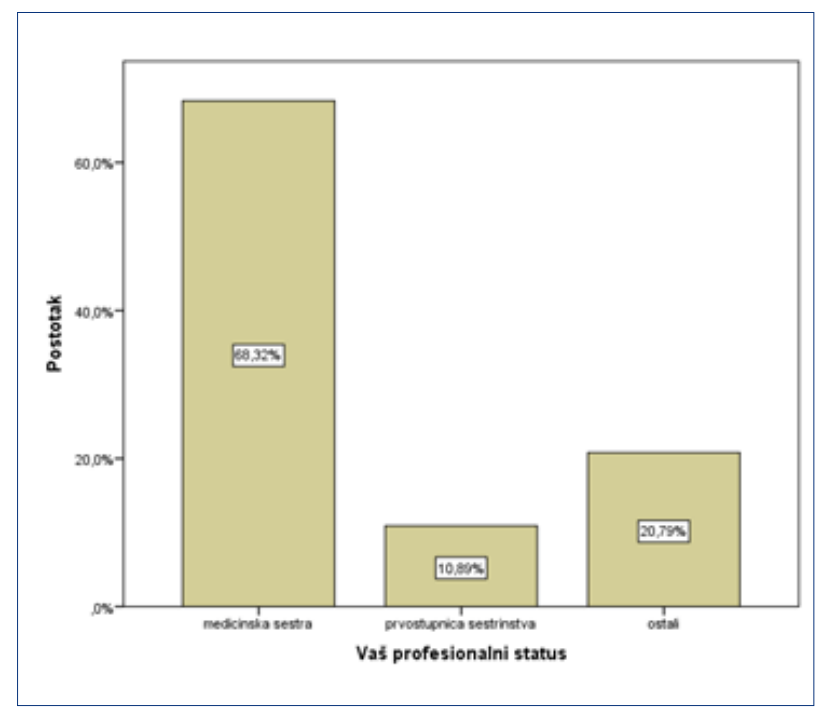

Grafikon 1. Profesionalni status ispitanika

S obzirom na godine radnog iskustva u struci (odnosi se na zaposlene studente) najveći je postotak ispitanika $(59,4 \%)$ imao radni staž u struci do pet godina $(23,8 \%$ između 5 i 10 godina, a 16,8 \% ispitanika imalo je radno iskustvo duže od 10 godina) (grafikon 2).

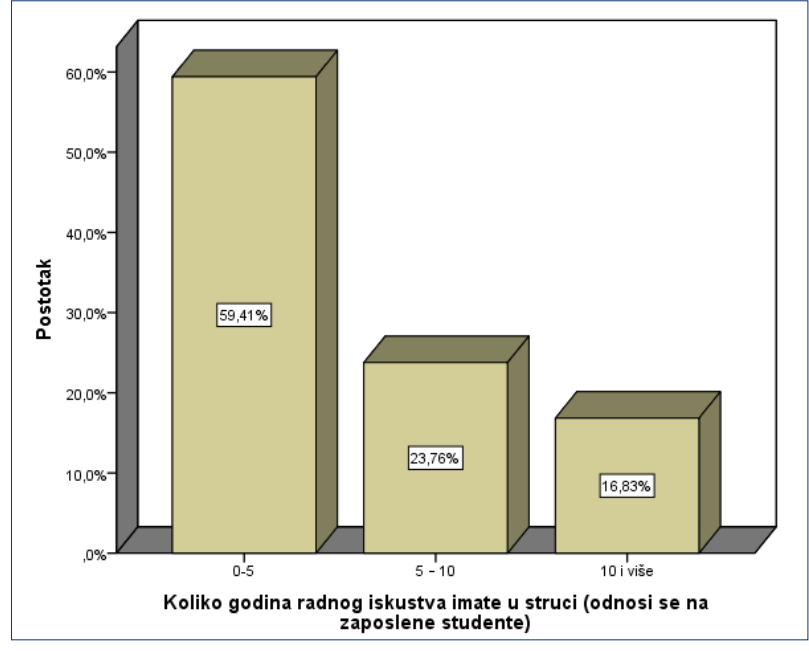

\section{Grafikon 2. Radno iskustvo ispitanika u struci}

Prema godini pohađanja studija najveći su postotak ispitanika bili s prve $(25,7 \%)$ i druge godine preddiplomskog studija $(24,8 \%)$ te apsolventi $(23,7 \%)$. Manji udio ispitanika bio je $s$ treće godine preddiplomskog $(11,9 \%)$ i druge godine diplomskog studija (13,6 \%). Prva godina diplomskog studija nedostaje u prikazu zato što se diplomski studij kliničkog sestrinstva na Sveučilištu u Dubrovniku upisuje svake druge godine te u godini istraživanja prva godina nije mogla biti obuhvaćena (grafikon 3).

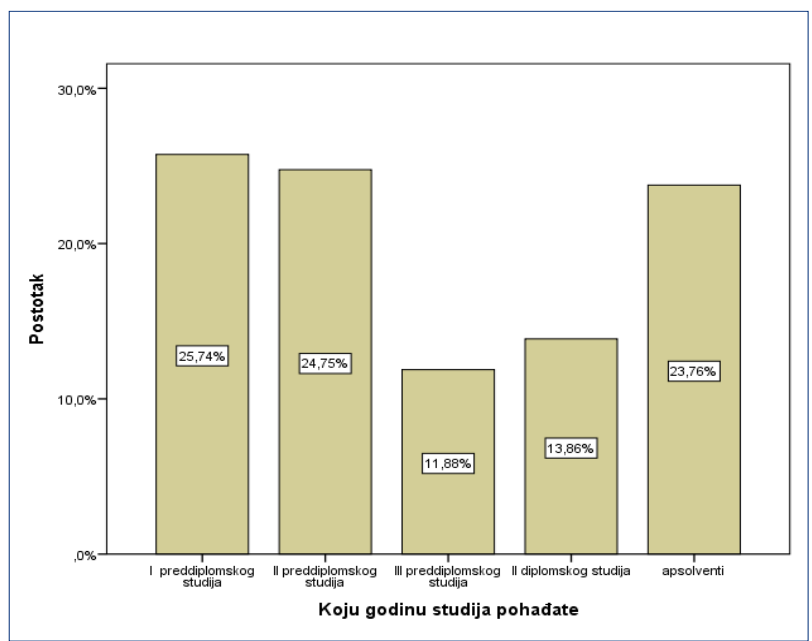

Grafikon 3. Godina pohađanja studija ispitanika

Iz tablice 2 može se uočiti da je većina ispitanika smatrala da je dobro što se danas u izvedbeni plan studija uveo predmet PS (55,4\%), 16,8 \% ispitanika smatra da nije dobro, a 27,7 \% ih ne zna.

Veći postotak ispitanika u svojem se radu također susre- 


\begin{tabular}{|c|c|c|c|}
\hline & & $\mathrm{N}$ & $\%$ \\
\hline \multirow{4}{*}{ Smatrate li da je dobro što se danas u izvedbeni plan studija uveo predmet PS? } & da & 56 & $55,4 \%$ \\
\hline & ne & 17 & $16,8 \%$ \\
\hline & ne znam & 28 & $27,7 \%$ \\
\hline & ukupno & 101 & $100,0 \%$ \\
\hline \multirow{3}{*}{ Susrećete li se u svojem radu s bolesnicima koji trebaju PS (odnosi se na zaposlene studente)? } & da & 55 & $54,5 \%$ \\
\hline & ne & 46 & $45,5 \%$ \\
\hline & ukupno & 101 & $100,0 \%$ \\
\hline \multirow{4}{*}{$\begin{array}{l}\text { Je li medicinskim sestrama za rad u ustanovama koje pružaju palijativnu skrb potrebna dodatna } \\
\qquad \text { edukacija? }\end{array}$} & $\mathrm{da}$ & 52 & $51,5 \%$ \\
\hline & ne & 20 & $19,8 \%$ \\
\hline & ne znam & 29 & $28,7 \%$ \\
\hline & ukupno & 101 & $100,0 \%$ \\
\hline
\end{tabular}

će s bolesnicima koji trebaju PS (odnosi se na zaposlene studente) (54,5\%), a 45,5\% ispitanika ne susreće se s PS-om.

Također, većina ispitanika smatra da je u ustanovama koje pružaju palijativnu skrb potrebno osigurati dodatnu edukaciju medicinskim sestrama/tehničarima iz područja PS-a (51,5\%), dok 19,8\% ispitanika smatra da dodatna edukacija iz PS-a nije potrebna, a 28,7 \% ispitanika ne zna je li edukacija iz PS-a potrebna (tablica 2 ).

U tablici 3 prikazani su odgovori ispitanika na 20 pitanja o palijativnoj skrbi prema anketnom upitniku PCQN.
Najviše točnih odgovora ispitanika bilo je povezano s razumijevanjem važnosti prisutnosti članova obitelji uz krevet umirućeg bolesnika (75\%), konstatacijom da patnja i fizička bol nisu jednoznačne $(74,3 \%)$ te da se manifestacija kronične boli razlikuje od manifestacije akutne boli (42,6\%).

Ispitanici su se također u visokom postotku točnih odgovora izjasnili da je filozofija PS-a kompatibilna s aktivnim liječenjem (akutnog zbivanja palijativnog bolesnika) $(40,6 \%)$ te da je upotreba placeba prikladna u liječenju pojedine vrste boli (39,9\%) (tablica 3).

\section{Tablica 3. Odgovori ispitanika na 20 pitanja o palijativnoj skrbi prema anketnom upitniku PCQN}

1. Palijativna skrb je prikladna jedino u situacijama kada je evidentno pogoršanje bolesti i propadanje.

2. Morfij je standard koji se primjenjuje za usporedbu analgetskog učinka drugih opioida.

3. Opseg bolesti određuje način liječenja boli.

4. Adjuvantna terapija bitna je u liječenju boli.

5. Vrlo je važno da članovi obitelji budu uz krevet bolesnika dok ne nastupi smrt.

6. U zadnjim danima života pospanost povezana s elektrolitskim disbalansom umanjuje potrebu za sedacijom.

\begin{tabular}{|c|c|c|}
\hline & $\mathrm{N}$ & $\%$ \\
\hline točno & 56 & $55,4 \%$ \\
\hline netočno & 25 & $24,8 \%$ \\
\hline ne znam & 20 & $19,8 \%$ \\
\hline ukupno & 101 & $100,0 \%$ \\
\hline točno & 25 & $24,8 \%$ \\
\hline netočno & 46 & $45,5 \%$ \\
\hline ne znam & 30 & $29,7 \%$ \\
\hline ukupno & 101 & $100,0 \%$ \\
\hline točno & 64 & $63,4 \%$ \\
\hline netočno & 21 & $20,8 \%$ \\
\hline ne znam & 16 & $15,8 \%$ \\
\hline ukupno & 101 & $100,0 \%$ \\
\hline točno & 29 & $28,7 \%$ \\
\hline netočno & 21 & $20,8 \%$ \\
\hline ne znam & 51 & $50,5 \%$ \\
\hline ukupno & 101 & $100,0 \%$ \\
\hline točno & 76 & $75,2 \%$ \\
\hline netočno & 9 & $8,9 \%$ \\
\hline ne znam & 16 & $15,8 \%$ \\
\hline ukupno & 101 & $100,0 \%$ \\
\hline točno & 27 & $26,7 \%$ \\
\hline netočno & 26 & $25,7 \%$ \\
\hline ne znam & 48 & $47,5 \%$ \\
\hline ukupno & 101 & $100,0 \%$ \\
\hline & & \\
\hline
\end{tabular}


7. Ovisnost o lijekovima veliki je problem kod duže primjene morfija u liječenju boli.

8. Osobe koji uzimaju opioide moraju uzimati i laksative.

\begin{tabular}{|c|c|c|}
\hline točno & 39 & $38,6 \%$ \\
\hline netočno & 32 & $31,7 \%$ \\
\hline ne znam & 30 & $29,7 \%$ \\
\hline ukupno & 101 & $100,0 \%$ \\
\hline točno & 28 & $27,7 \%$ \\
\hline netočno & 34 & $33,7 \%$ \\
\hline ne znam & 39 & $38,6 \%$ \\
\hline ukupno & 101 & $100,0 \%$ \\
\hline točno & 52 & $51,5 \%$ \\
\hline netočno & 10 & $9,9 \%$ \\
\hline ne znam & 39 & $38,6 \%$ \\
\hline ukupno & 101 & $100,0 \%$ \\
\hline točno & 18 & $17,8 \%$ \\
\hline netočno & 11 & $10,9 \%$ \\
\hline ne znam & 72 & $71,3 \%$ \\
\hline ukupno & 101 & $100,0 \%$ \\
\hline točno & 68 & $67,3 \%$ \\
\hline netočno & 12 & $11,9 \%$ \\
\hline ne znam & 21 & $20,8 \%$ \\
\hline ukupno & 101 & $100,0 \%$ \\
\hline točno & 26 & $25,7 \%$ \\
\hline netočno & 41 & $40,6 \%$ \\
\hline ne znam & 34 & $33,7 \%$ \\
\hline ukupno & 101 & $100,0 \%$ \\
\hline točno & 40 & $39,6 \%$ \\
\hline netočno & 39 & $38,6 \%$ \\
\hline ne znam & 22 & $21,8 \%$ \\
\hline ukupno & 101 & $100,0 \%$ \\
\hline točno & 26 & $25,7 \%$ \\
\hline netočno & 22 & $21,8 \%$ \\
\hline ne znam & 53 & $52,5 \%$ \\
\hline ukupno & 101 & $100,0 \%$ \\
\hline točno & 9 & $8,9 \%$ \\
\hline netočno & 75 & $74,3 \%$ \\
\hline ne znam & 17 & $16,8 \%$ \\
\hline ukupno & 101 & $100,0 \%$ \\
\hline točno & 11 & $10,9 \%$ \\
\hline netočno & 34 & $33,7 \%$ \\
\hline ne znam & 56 & $55,4 \%$ \\
\hline ukupno & 101 & $100,0 \%$ \\
\hline točno & 36 & $35,6 \%$ \\
\hline netočno & 19 & $18,8 \%$ \\
\hline ne znam & 46 & $45,5 \%$ \\
\hline ukupno & 101 & $100,0 \%$ \\
\hline točno & 43 & $42,6 \%$ \\
\hline netočno & 17 & $16,8 \%$ \\
\hline ne znam & 41 & $40,6 \%$ \\
\hline ukupno & 101 & $100,0 \%$ \\
\hline točno & 83 & $82,2 \%$ \\
\hline netočno & 3 & $3,0 \%$ \\
\hline ne znam & 15 & $14,9 \%$ \\
\hline ukupno & 101 & $100,0 \%$ \\
\hline točno & 38 & $37,6 \%$ \\
\hline netočno & 36 & $35,6 \%$ \\
\hline ne znam & 27 & $26,7 \%$ \\
\hline ukupno & 101 & $100,0 \%$ \\
\hline
\end{tabular}

20. Tjeskoba ili umor smanjuju prag boli. 
U tablici 4 prikazan je udio točnih odgovora ispitanika po postavljenom pitanju o PS-u.

Ispitanici su prosječno točno odgovorili na sedam pitanja ili na ukupno jednu trećinu (34,8 \%) postavljenih pitanja o PS-u (tablica 5). Najveći broj ispitanika imao je sedam $(25,7 \%)$ i osam (24,8 \%) točnih odgovora (grafikon 4$)$.

\begin{tabular}{|c|c|c|}
\hline & $\mathrm{N}$ & $\%$ \\
\hline $\begin{array}{l}\text { 1. Palijativna skrb prikladna je jedino u situacijama kada je evidentno pogoršanje bolesti i } \\
\text { propadanje. }\end{array}$ & 25 & $24,8 \%$ \\
\hline 2. Morfij je standard koji se primjenjuje za usporedbu analgetskog učinka drugih opioida. & 25 & $24,8 \%$ \\
\hline 3. Opseg bolesti određuje način liječenja boli. & 21 & $20,8 \%$ \\
\hline 4. Adjuvantna terapija bitna je u liječenju boli. & 29 & $28,7 \%$ \\
\hline 5. Vrlo je važno da članovi obitelji budu uz krevet bolesnika dok ne nastupi smrt. & 76 & $75,2 \%$ \\
\hline $\begin{array}{l}\text { 6. U zadnjim danima života pospanost povezana s elektrolitskim disbalansom umanjuje potrebu za } \\
\text { sedacijom. }\end{array}$ & 27 & $26,7 \%$ \\
\hline 7. Ovisnost o lijekovima veliki je problem kod duže primjene morfija u liječenju boli. & 32 & $31,7 \%$ \\
\hline 8. Osobe koji uzimaju opioide moraju uzimati i laksative. & 34 & $33,7 \%$ \\
\hline 9. Pružanje palijativne skrbi zahtijeva emocionalni odmak. & 10 & $9,9 \%$ \\
\hline $\begin{array}{l}\text { 10. Lijekovi koji mogu izazvati zatajivanje disanja prikladni su za liječenje teške dispneje u terminalnoj } \\
\text { fazi bolesti. }\end{array}$ & 11 & $10,9 \%$ \\
\hline 11. Muškarci se nose s tugom lakše od žena. & 12 & $11,9 \%$ \\
\hline 12. Filozofija palijativne skrbi kompatibilna je s aktivnim liječenjem. & 41 & $40,6 \%$ \\
\hline 13. Upotreba placeba prikladna je u liječenju nekih tipova boli. & 40 & $39,6 \%$ \\
\hline 14. U velikim dozama kodein uzrokuje veću mučninu i povraćanje od morfija. & 26 & $25,7 \%$ \\
\hline 15. Patnja i fizička bol su jedno te isto. & 75 & $74,3 \%$ \\
\hline 16. Dolantin nije učinkovit lijek u liječenju kronične boli. & 11 & $10,9 \%$ \\
\hline 17. Izgaranje zbog akumulacije gubitaka neizbježno je za one koji rade u palijativnoj skrbi. & 36 & $35,6 \%$ \\
\hline 18. Manifestacija kronične boli razlikuje se od manifestacije akutne boli. & 43 & $42,6 \%$ \\
\hline 19. Gubitak osobe s kojom nismo bliski lakše se podnosi od gubitka bliske osobe. & 83 & $82,2 \%$ \\
\hline 20. Tjeskoba ili umor smanjuju prag boli. & 38 & $37,6 \%$ \\
\hline
\end{tabular}




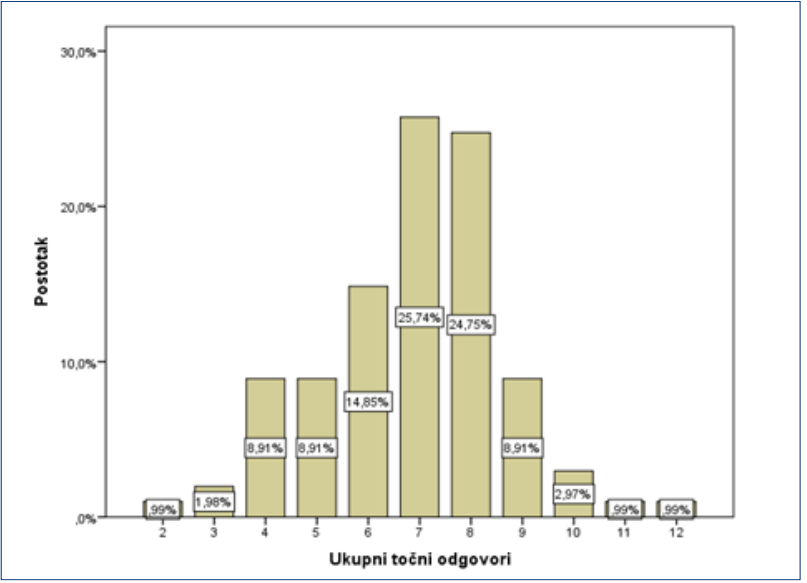

Grafikon 4. Udio ispitanika s jednakim brojem točnih odgovora o palijativnoj skrbi

\section{Testiranje razlike znanja kod promatranih sociodemografskih pokazatelja}

Testiranje razlike raspona znanja ispitanika, tj. ukupnih točnih odgovora o palijativnoj skrbi s obzirom na sociodemografske pokazatelje provedeno je testovima analize varijance Mann-Whitneyjevim U-testom i KruskalWallisovim testom s obzirom na:

\section{Spol ispitanika}

Muški ispitanici imali su statistički signifikantno višu razliku raspona znanja u usporedbi s ispitanicama $(p=0,032)$ (tablica 6$)$.

\begin{tabular}{|c|c|c|}
\hline & $\begin{array}{c}\text { Broj } \\
\text { točnih } \\
\text { odgovora } \\
(\mathrm{N} / 20)\end{array}$ & $\begin{array}{l}\text { Ispitanici } \\
\text { (N/101) }\end{array}$ \\
\hline & 2 & 1 \\
\hline & 3 & 2 \\
\hline & 4 & 9 \\
\hline & 5 & 9 \\
\hline & 6 & 15 \\
\hline & 7 & 26 \\
\hline & 8 & 25 \\
\hline & 9 & 9 \\
\hline & 10 & 3 \\
\hline & 11 & 1 \\
\hline & 12 & 1 \\
\hline Ukupno (N): & 703 & 101 \\
\hline Udio (\%): & 34,8 & 100 \\
\hline $\bar{x}=$ aritmetička sredina & 6,88 & \\
\hline $\mathrm{Sd}=$ standardna devijacija & 1,78 & \\
\hline
\end{tabular}

\begin{tabular}{|c|c|c|c|c|c|}
\hline \multicolumn{6}{|c|}{ Tablica 6. Razlike raspona znanja, tj. ukupnih točnih odgovora o PS-u s obzirom na spol ispitanika } \\
\hline & Spol & $\begin{array}{c}\text { N } \\
(101)\end{array}$ & $\begin{array}{c}\text { Aritmetička } \\
\text { sredina raspona }\end{array}$ & $\begin{array}{c}\text { Suma } \\
\text { raspona }\end{array}$ & $\begin{array}{c}\text { Testna statistika za } \\
\text { varijablu spol }\end{array}$ \\
\hline Ukupni točni odgovori & ženski & 91 & 48,97 & 4456,50 & \\
\hline muški & 10 & 69,45 & 694,50 & \\
\hline Mann-Whitneyjev U-test & & & & & 4456,500 \\
\hline Wilcoxonov W-test & & & $-2,138$ \\
\hline Z & & & 0,032 \\
\hline
\end{tabular}




\section{Dob ispitanika}

Pogleda li se vrijednost signifikantnosti s obzirom na dob ispitanika, može se uočiti kako signifikantnost testa iznosi više od $5 \%(p=0,965)$ te se stoga može konstatirati kako dob nema značajnu ulogu kod ukupnih točnih odgovora ispitanika (tablica 7).

\begin{tabular}{|c|c|c|c|}
\hline \multicolumn{6}{|c|}{ Tablica 7. Razlike raspona znanja, tj. ukupnih točnih odgovora s obzirom } \\
na dob ispitanika
\end{tabular}

\section{Profesionalni status ispitanika}

Pogleda li se vrijednost signifikantnosti s obzirom na profesionalni status ispitanika, može se uočiti kako signifikantnost testa iznosi više od $5 \%(p=0,197)$ te se stoga može konstatirati kako profesionalni status nema značajnu ulogu kod ukupnih točnih odgovora ispitanika (tablica 8).

\begin{tabular}{|c|c|c|c|c|}
\hline \multicolumn{2}{|c|}{ Tablica 8. Razlike raspona znanja, tj. ukupnih točnih odgovora s obzirom } \\
na profesionalni status ispitanika
\end{tabular}




\section{Godine radnoga iskustva}

Godine radnoga iskustva u struci (odnosi se na zaposlene studente) nisu imale statistički značajnu ulogu na ukupne točne odgovore ispitanika $(p=0,922)$ (tablica 9).

\begin{tabular}{|c|c|c|c|c|}
\hline \multicolumn{8}{|c|}{ Tablica 9. Razlike raspona znanja, tj. ukupnih točnih odgovora s obzirom } \\
na godine radnoga iskustva u struci \\
\hline \\
\begin{tabular}{c|c|c|c|} 
Radno iskustvo \\
u struci (odnosi \\
se na zaposlene \\
studente) \\
(godine)
\end{tabular} & $\begin{array}{c}\mathrm{N} \\
(101)\end{array}$ & $\begin{array}{c}\text { Aritmetička } \\
\text { sredina raspona }\end{array}$ & $\begin{array}{c}\text { Testna statistika za } \\
\text { varijablu radno iskustvo } \\
\text { (Kruskal-Wallisov test) }\end{array}$ \\
\hline Ukupni točni odgovori & $0-5$ & 60 & 51,95 & \\
\hline Hi-kvadrat test & $5-10$ & 24 & 49,60 & 0,161 \\
\hline df & 10 i više & 17 & 49,62 & 2 \\
\hline P (Asymp. Sig.) & & & & 0,922 \\
\hline
\end{tabular}

\section{Godina studija}

Pogleda li se vrijednost signifikantnosti za godinu studija, može se uočiti kako $p$ iznosi manje od $5 \%(p=0,008)$ te se s razinom pouzdanosti od $95 \%$ može reći kako postoji statistički značajna razlika za godinu studija s obzi- rom na ukupne točne odgovore. Pri tome se u tablici 10 može uočiti kako su rasponi značajno najviši (prisutno je najviše točnih odgovora) kod ispitanika na trećoj godini preddiplomskog studija (tablica 10).

\begin{tabular}{|c|c|c|c|c|}
\hline \multicolumn{2}{|c|}{ Tablica 10. Razlike raspona znanja, tj. ukupnih točnih odgovora sobzirom } \\
na godine radnoga iskustva u struci
\end{tabular}




\section{Mišljenje studenata o potrebi uvođenja kolegija o palijativnoj skrbi}

Mišljenje studenata da je dobro da se na studij uveo kolegij o palijativnoj skrbi nije imalo signifikantnu ulogu na razliku raspona znanja ispitanika $(p=0,274)$ (tablica 11$)$.

\begin{tabular}{|c|c|c|c|c|}
\hline \multicolumn{8}{|c|}{$\begin{array}{c}\text { Tablica 11. Razlike raspona znanja, tj. ukupnih točnih odgovora s obzirom } \\
\text { na mišljenje studenata o potrebi uvođenja kolegija o PS-u }\end{array}$} \\
\hline & $\begin{array}{c}\text { Smatrate li da } \\
\text { je dobro što } \\
\text { se u izvedbeni } \\
\text { plan studija } \\
\text { uveo predmet } \\
\text { Palijativna skrb? }\end{array}$ & $\begin{array}{c}\text { N } \\
(101)\end{array}$ & $\begin{array}{c}\text { Aritmetička } \\
\text { sredina raspona }\end{array}$ & $\begin{array}{c}\text { Testna statistika za varijablu } \\
\text { Smatrate li da je dobro što je } \\
\text { premet PS uveden u izvedbeni } \\
\text { program studija? }\end{array}$ \\
\hline Ukupni točni odgovori & da & 56 & 48,90 & \begin{tabular}{c} 
(Kruskal-Wallisov test) \\
\hline ne
\end{tabular} \\
\hline Hi-kvadrat test & ne znam & 28 & 61,24 & 2,592 \\
\hline df & & & 48,98 & 2 \\
\hline P (Asymp. Sig.) & & & & 0,274 \\
\hline
\end{tabular}

\section{Prisutnost bolesnika s potrebom za PS u radu ispitanika}

Pogleda li se vrijednost signifikantnosti, s obzirom na to susreću li se ispitanici u svojem radu s bolesnicima koji trebaju PS (odnosi se na zaposlene studente), može se uočiti kako signifikantnost testa iznosi više od $5 \%$ $(p=0,909)$ te se stoga može konstatirati da iako se ispitanici u svojem radu susreću s bolesnicima koji trebaju PS (odnosi se na zaposlene studente), to nije imalo značajnu ulogu na ukupne točne odgovore ispitanika (tablica 12).

\begin{tabular}{|c|c|c|c|c|}
\hline \multicolumn{8}{|c|}{ Tablica 12. Razlike raspona znanja, tj. ukupnih točnih odgovora s obzirom } \\
na PS kao sastavni dio rada ispitanika
\end{tabular}




\section{Mišljenje ispitanika o dodatnoj edukaciji osoblja iz PS-a u ustanovama koje je pružaju}

Pogleda li se vrijednost signifikantnosti s obzirom na pitanje Je li medicinskim sestrama za rad u ustanovama koje pružaju palijativnu skrb potrebna dodatna edukacija? može se uočiti kako signifikantnost testa iznosi više od $5 \%(p=0,281)$ te se može konstatirati kako postavljeno pitanje nema značajnu ulogu kod ukupnih točnih odgovora ispitanika (tablica 13).

\section{Tablica 13. Razlike raspona znanja tj. ukupnih točnih odgovora s obzirom na mišljenje ispitanika o potrebi za dodatnom edukacijom osoblja u ustanovama koje pružaju PS}

\begin{tabular}{|c|c|c|c|c|}
\hline & $\begin{array}{c}\text { Je li medicinskim } \\
\text { sestrama za rad u } \\
\text { ustanovama koje } \\
\text { pružaju palijativnu } \\
\text { skrb potrebna dodatna } \\
\text { edukacija? }\end{array}$ & $\begin{array}{c}\mathrm{N} \\
(101)\end{array}$ & $\begin{array}{c}\text { Aritmetička } \\
\text { sredina } \\
\text { raspona }\end{array}$ & $\begin{array}{c}\text { Testna statistika } \\
\text { za varijablu Je li } \\
\text { potrebna dodatna } \\
\text { edukacija osoblja za } \\
\text { rad u ustanovama } \\
\text { koje pružaju PS? } \\
\text { (Kruskal Wallis test) }\end{array}$ \\
\hline \multirow{3}{*}{ Ukupni točni odgovori } & da & 52 & 52,13 & \\
\hline & ne & 20 & 57,43 & \\
\hline & ne znam & 29 & 44,55 & \\
\hline Hi-kvadrat test & & & & 2,538 \\
\hline df & & & & 2 \\
\hline P (Asymp. Sig.) & & & & 0,281 \\
\hline
\end{tabular}

\section{RASPRAVA}

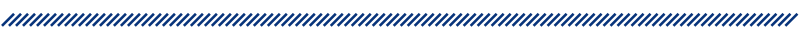

Sigurno je da se s povećanjem broja stanovništva i produženjem životne dobi s jedne strane te povećanjem ukupne stope preživljenja uslijed suvremenih metoda liječenja kroničnih i malignih bolesti s druge strane proporcionalno povećava broj bolesnika koji imaju potrebu za palijativnom skrbi. Tako potreba bolesnika za palijativnom skrbi postaje globalni zahtjev na nacionalnoj razini. ${ }^{12}$ Razvoj palijativne skrbi danas je odmaknuo u visokorazvijenim zemljama (Amerika, Europa), ali i zemljama s mnogobrojnim stanovništvom (Kina, Indija). Neovisno o tome je li riječ o stanovništvu sofisticirane zapadne ili tradicionalne istočne medicine, palijativna skrb čini nezaobilaznu sastavnicu u humanom, moralnom i etičkom zbrinjavanju palijativnih bolesnika.

Kako bi se unaprijedila kvaliteta palijativne skrbi i obuhvatio što veći broj potrebitih bolesnika, vrlo brzo postalo je jasno da se to može postići uz osmišljenu edukaciju sestrinstva i usvojenu evaluaciju stečenih kompeticija i vještina. Upitnik PCQN od svojeg se nastanka 1996. primjenjivao u velikom broju istraživanja u bolnicama i u domovima za stare i nemoćne. Autori su provodili različite vrste studija, poput istraživanja s kontrolnom skupinom (Adriaansen, van Achterberg $\mathrm{i}$ Borm 2005). Hiwot je s grupom autora radio istraživanje u Addis Ababi u Etiopiji o znanju medicinskih sestara o palijativnoj skrbi na uzorku od 365 medicinskih sestara u više bolnica. ${ }^{10}$

Jiang i suradnici 2019. u svojem su radu istaknuli da su upravo studenti preddiplomskog studija sestrinstva glavni nositelji buduće kvalitete palijativne skrbi te da upravo zbog toga treba edukativni dio programa usmjeriti upravo prema njima. ${ }^{12}$

Edukacija iz palijativne skrbi dosad se provodila sporadično, uglavnom kroz satnicu drugih predmeta. Odnedavno je u sklopu Sveučilišta u Dubrovniku započeta planski programirana nastava iz palijativne skrbi u sklopu zasebnog predmeta Palijativna skrb. To objašnjava relativno manji broj sudionika u anketnom upitniku ( $N=101)$, no većinskim udjelom, kao i kod drugih istraživanja, s preddiplomskog (63\%) studija, zdravstvenog 
usmjerenja (80\%), ženskog spola (91\%) i u dobi do 24 godine (62\%).

Evaluacija znanja, vještina, edukacije i poimanja studenata o palijativnoj skrbi za naše područje još do sada nije učinjena. Time čini vrijedan temeljni podatak za buduće usporedbe interinstitucionalnog i intrainstitucionalnoga tipa.

Naši su ispitanici prosječno točno odgovorili na sedam od 20 pitanja o PS-u. Iz tablice 5 također se može vidjeti da je daleko veći broj ispitanika (93\%) točno odgovorio na $<50 \%$ pitanja, a samo $7 \%$ ispitanika na $\geq 50 \%$ pitanja. Samo 12 ispitanika (12\%) odgovorilo je točno na manje od pet pitanja, ali nijedan student nije imao više od 12 točnih odgovora. Niži prvobitni rezultati kod naših ispitanika u usporedbi $s$ istovrsnim studijama drugih autora ukazuju na činjenicu da među našim ispitanicima postoji temeljno znanje o palijativnoj skrbi koje zahtijeva daljnju sustavnu edukaciju, osobito ako će nastavak njihova rada biti povezan s palijativnom skrbi. O'Shea i Mager 2019. u Americi su ukazali da se nacionalnim edukacijskim programom (ELNEK; End-of-LifeNursing Education Consortium) znatno pridonosi stjecanju vještina medicinskih sestara koje rade u bliskom radu s bolesnicima u PS-u. Budući da je riječ o visokorazvijenoj zemlji, analizom točnih odgovora upitnika PCQN prije (13/20) i nakon završene edukacije (15/20) zabilježili su signifikantan porast u znanju, tj. postignutim točnim odgovorima. S druge strane, kineski autori Jiang i suradnici 2016. analizirali su 1200 studenata preddiplomskog studija uz upitnik PCQN dopunjen dodatnim pitanjima prema njihovim specifičnostima. lako je prosječan skor točnih odgovora iznosio $16+/-5$, zaključili su da je to još uvijek nisko znanje studenata iz palijativne skrbi s obzirom na cjelokupnu zahtjevnost rada s palijativnim bolesnicima. ${ }^{13}$ Jiang u svojem radu također ističe da na stjecanje znanja i vještina iz palijativne skrbi utječu stupanj i vrsta edukacije, spol, mjesto rođenja i religijska uvjerenja. Osobito je važna informacija koju su istaknuli ovi autori da neovisno o edukaciji, svake godine oko $19 \%$ djelatnika u palijativnoj skrbi zbog zahtjevnosti samoga rada i pristupa bolesniku odustaje od daljnjega rada u palijativnoj skrbi. U Grčkoj su prema provedenoj evaluaciji znanja i vještina uz pomoć upitnika PCQN i FATCOD (Frommelt Attitudes Towards Care of the Dying questionnaire) na 529 studenata s preddiplomskih i diplomskih studija dvaju sveučilišta zaključili da je znanje studenata o palijativnoj skrbi nisko, a o prepoznavanju simptoma boli te psihosocijalnoj i duhovnoj njezi manjkavo. U svrhu poboljšanja predlažu provođenje tematskih i strukturiranih tečajeva iz palijativne skrbi u sklopu preddiplomskih studija. Ovakva integrirana edukacija trebala bi obratiti osobitu pažnju u području unaprjeđenja kvalitetne i tople komunikacije između bolesnika i medicinske sestre, vještine izbjegavanja zabluda, nedoumica i nesporazuma, kao i pripreme zdravstvenog djelatnika na sam suživot s bolesnikom tijekom umiranja i smrti. ${ }^{14}$

Iz rezultata naših ispitanika vrijedno je istaknuti da su muškarci, iako malobrojniji, bili uspješniji u ukupnom broju točnih odgovora o PS-u $(p=0,032)$, kao i godinu pohađanja studija $(p=0,008)$. Dob, profesionalni status i godine radnog iskustva nisu bili od značenja u razini znanja ispitanika o PS-u $(p>0,05)$. Budući da je riječ o relativno malom uzorku ispitanika, kratkom vremenu upoznavanja s problematikom PS-a te prvom ovakvom provedenom testiranju, s oprezom je potrebno protumačiti dobivene rezultate, koji nisu ukazali na očekivani znatan porast znanja iako su ispitanici bili u prilici susretati bolesnike s potrebom za PS-om te imali pozitivan stav o potrebi dopunske edukacije o PS-u za osoblje koje radi u institucijama koje pružaju palijativnu skrb, kao i organiziranog uvođenja predmeta Palijativna skrb kao dijela studija sestrinstva.

\section{ZAKLJUČAK}

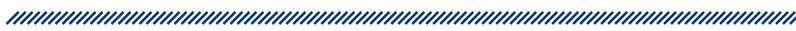

Možemo reći da je palijativna skrb još uvijek je nepoznanica, pojam koji se sve više spominje, ali, nažalost, još se uvijek dovoljno ne uvažava. Provedeno istraživanje sigurno je potvrdilo da su ispitanici imali pozitivne stavove o dodatnoj edukaciji, kao i slušanju kolegija kroz obrazovni sustav. Nameće se zaključak da bi se i upoznavanje s pojmom i samom palijativnom skrbi već trebalo početi provoditi na srednjoškolskoj razini, kako bi studenti na studiju već poznavali pojam, a ne bi se s njim tek upoznavali, što bi vjerojatno polučilo bolje rezultate u smislu znanja i poznavanja pojma.

Unatoč navedenom, ako pogledamo posljednje desetljeće, možemo biti zadovoljni samim time što danas nema županije koja u svojem djelovanju nema organiziran neki od oblika pružanja palijativne skrbi. Kontinuirana edukacija kako studenata tako i lokalnih zajednica i dionika zdravstvenog sustava sigurno će u budućnost pokazati mnogo više znanja i poznavanja pojma i potreba palijativne skrbi. 


\section{LITERATURA}

1. European journal of palliative care. Bijela knjiga o standardima i normativima za hospicijsku i palijativnu skrb u Europi, preporuke Europskog udruženja za palijativnu skrb. 2009., 16 (6) 279.

2. Đorđević V, Braš M, Brajković L. Osnove palijativne medicine. Zagreb: Medicinska naklada, 2013.

3. 3. Kindlen JLM. Palijativna njega - Uloga sestrinstva. Churchill Livingstone, 1999; str. 1-244.

4. Đorđević V, Braš M, Brajković L. Palijativna skrb: Mostovi nade i čovječnosti. Zagreb: Roketa, 2012; str. 4-156.

5. 5. Braš M, Đorđević V. Služiti čovjeku - Putokazi humanost u medicini. Zagreb: Medicinski fakultet Sveučilišta u Zagrebu, 2018.

6. Brkljačić M. Bioetika i bioetički aspekti palijativne medicine. Medicina Fluminensis, 2008, 44 (2), 146-151. Dostupno na: https://hrcak.srce.hr/26838 (pristupljeno 28.3.2019.).

7. Sveučilište u Dubrovniku, Odjel za stručne studije. Izvedbeni plan nastave za akademsku godinu 2018./2019., Preddiplomski stručni studij: Sestrinstvo, str. 145-147.

8. Sveučilište u Dubrovniku, Odjel za stručne studije. Izvedbeni plan nastave za akademsku godinu 2018./2019., Diplomski studij: Kliničko sestrinstvo, str 88-90.

9. Centar za palijativnu medicinu, medicinsku etiku i komunikacijske vještine Medicinskog fakulteta Sveučilišta u Zagrebu (CEPAMET). Dostupno na: http://mef.unizg. hr/o-nama/ustroj/centri/centar-za-palijativnu-medicinu-medicinsku-etiku-i-komunikacijske-vjestine

10. Ross MM, McDonald B, McGuinness J. The palliative care quiz for nursing (PCQN): the development of an instrument to measure nurses' knowledge of palliative care. J Adv Nurs. 1996 Jan; 23 (1): 126-137.

11. Lovrić S. Spoznaje medicinskih sestara u bolnici o palijativnoj skrbi. Diplomski rad.

12. Jiang Q, Lu Y, Ying Y, Zhao H. Attitudes and knowledge of undergraduate nursing students about palliative care: An analysis of influencing factors. Nurse Educ Today. 2019; 80: 15-21.

13. O'Shea ER, Mager D. End-of-life nursing education: Enhancing nurse knowledge and attitudes. Appl Nurs Res. 2019; 50: 151197.

14. Dimoula M, Kotronoulas G, Katsaragakis S, Christou M, Sgourou S, Patiraki E. Undergraduate nursing students' knowledge about palliative care and attitudes towards end-of-life care: A three-cohort, cross-sectional survey. Nurse Educ Today. 2019; 74: 7-14. 


\section{THOUGHTS AND LEVEL OF KNOWLEDGE ABOUT PALLIATIVE CARE AMONG NURSING STUDENTS IN DUBROVNIK}

\author{
1 Vedrana Iveta \\ 2 Mara Županić \\ 3 Dubravka Bartolek Hamp \\ 4 Anita Miljas \\ 1 Dom zdravlja Dubrovnik \\ 2 Zdravstveno veleučilište Zagreb \\ 3 Klinički bolnički centar Zagreb \\ 4 Opća bolnica Dubrovnik
}

\section{Abstract

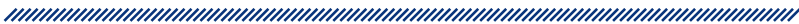

Introduction: Palliative care (PC) is still a big unknown. Today, after about 10 years of active use of this term in our country, a lack of knowledge is still quite common, both among health professionals and in the rest of the population. The term itself bears a "stigma" caused by insufficient knowledge and education. It is education that is the key element in the more active use of PC resources in all stages of the disease in patients who need such care. PC is a comprehensive care appropriate for a seriously ill patient whose needs are recognized and met using a multidisciplinary and holistic approach.

The aim of this study was to determine the knowledge and attitudes of nursing students about palliative care and to determine the extent to which their age, education, and experience or occupation have an impact on their thinking about palliative care.
Research methods: The study was conducted using a voluntary and anonymous survey of students at the undergraduate and graduate levels of study of Nursing at the University of Dubrovnik. The survey included employed and unemployed students, and students from both medical and non-medical professions. The measuring instrument used in this study was a standardized PCQN (Palliative Care Quiz for Nurses) questionnaire. The questionnaire contains 20 questions related to the philosophy of palliative care, control of pain and associated disease symptoms, and psychological, spiritual, and social issues of PC. The possible answers were "correct", "incorrect", and "I do not know". Correct answers were awarded one point while incorrect answers and the answer "I do not know" were awarded zero points. The statistical analysis used the analysis of variance (ANOVA) along with the Kruskal Wallis and Mann-Whitney $U$ test.

Results: The majority of respondents thought that it was good that a course on PC has been introduced into the study plan (55.4\%). No student provided more than 12 correct answers. A comparison with similar studies shows that the respondents have a basic level of knowledge.

Keywords: nurse, nursing study, palliative care, PCQN questionnaire 